\title{
REVIEW \\ Raimo Hakola \\ Identity Matters: John, the Jews and Jewishness
}

(Supplements to Novum Testamentum ir8; Leiden and Boston: Brill, 2005), x +29I pp.

Reviewed by Claudia Setzer, Manhattan College

References to Jews and Judaism in the Fourth Gospel have puzzled and disturbed interpreters because they are contradictory, one set acknowledging Jewish privilege as the partners of the covenant and inheritors of Scripture, and the other condemning them in sometimes brutal language. Many interpreters have emphasized one set of remarks and tried of dispose of the other. Raimo Hakola has now put forth an interpretation that does justice to both.

He employs a model drawn from the work of Kari Syreeni whose "three world" model distinguishes between the world of the text, the symbolic world, and the real world. The gospel's apparent ambivalence about Jews and Judaism comes from the discrepancy between the real world and the symbolic world. Conflict with the Jews in John is not "real," but a useful symbolic motif. The Johannine community no longer identifies with the symbols of Judaism, because Jesus has replaced and superseded them. Jewish persecution is a motif that helps the community work out its own identity. It recognizes the former glory of the Jews and their symbols, but these retain no emotional weight for them.

One example will suffice. John tells the story of Jesus driving the money-changers and animals out of the Temple (2:13-22), seemingly presenting Jesus as a pious Jew anxious to reform and purify Jewish practices related to the physical Temple (vv. 14-16). A few verses later (vv. 1921) Jesus predicts the destruction of the Temple and shifts to the temple of his body. John's introduction of the sheep and oxen, a detail Hakola explains as unhistorical and scandalous to Jews, his ignorance of arrangements of the Temple, and his placing it at the beginning of the gospel, suggests that it serves a symbolic role in the narrative. Jewish failure to preserve the purity of the Temple justifies to John's readers its eventual destruction and replacement with the temple of Jesus' body. Although contemporary Jewish groups criticized other Jews who profaned the Temple, John's interpretive move to destruction and replacement takes him beyond Judaism. The Temple is drained of its value as a Jewish symbol and replaced with the only symbol that matters, Jesus. Thus John speaks to a community that views Judaism's symbols and practice as part of the past, a mere building block in construction of their distinctive identity as followers of Jesus. This episode, combined with the dialogue with the Samaritan woman, shows that true worship of the Father is something new. It will be neither in the Jerusalem Temple nor on Mount Gerizim, but among the followers of Jesus.

Hakola shows how his method explains other symbols: the Sabbath and circumcision, Jacob, Moses, and Abraham. The Johannine author gives a nod to the heritage of these markers of Jewishness, but cedes to them no independent value. Indeed, his Jesus turns them around, using them against his opponents in the gospel. If some members of the community still cling to aspects of Jewish identity, say the so-called "secret Christians" still in the synagogue or "the Jews who had believed in him" (8:31), John's rhetoric widens the breach by lumping all together 
as "the Jews," denying them their symbols, and calling them names like "children of the devil." His intense soteriological dualism allows no fence-sitters.

Hakola challenges consensuses old and new. He argues against the influential model of $\mathrm{J}$. Louis Martyn that saw the gospel as a two-level drama whose conflict between Jesus and "the Jews" is a cipher for the conflict between the Johannine community and an emerging rabbinic hegemony. Martyn's model makes an unwarranted leap from narrative to history, and imagines a powerful rabbinic orthodoxy that, most scholars would now agree, is rabbinic wishful thinking. On the other hand, Hakola rejects a current trend to see virtually all of early Christianity as a form of Judaism, a trend that renders early Christian identity almost meaningless. Nor does he allow an escape to a theological camp to avoid grappling with history.

The problem with such a carefully calibrated model that requires an inter-play between symbol, rhetoric, and reality, as well as between the author and his audience, is the one all text scholars face. How do we know which is which? The voice of the author is especially tricky, since, as Hakola understands him, he sometimes mirrors the community, but sometimes is at odds with them, trying to lead them in a different direction. His scholarship is thorough and up-to-date, although I would quibble with his identification of "the two great names in twentieth century Johannine scholarship" as C.H. Dodd and Rudolf Bultmann (6). Surely Raymond E. Brown and Rudolf Schnackenburg also belong on that list.

This is a judicious, carefully argued, and persuasive work. Its does not wish away one kind of reference to Jews in order to amplify the other in the service of a theory. Some past such attempts have done so, flirting with over-irenicism or anti-Semitism. He takes in current work on rabbinic Judaism, noting that the image of the rabbis has become much more nuanced in Jewish studies, while it has remained a caricature in much of Johannine studies.

The final chapter is a thoughtful reflection on current scholarship and on the implications of his model for Jewish-Christian relations. He notes that the scholars who have emphasized John's Jewishness do not solve the problem of anti-Judaism. To say that finding Jewishness precludes anti-Judaism is simplistic. While he hardly recommends adopting John's views of Jews and Judaism, he suggests that John's struggle with conflicting tendencies mirrors the task of today's Christian, struggling with multiple identities. Ignoring the dark side of works like John will not serve that struggle for identity.

Hakola's argument persuades this reader, and is, in many ways, refreshing. He moves us out of some old arguments and on to a new level. Any scholar working on John and the Jews needs to take account of this work. 